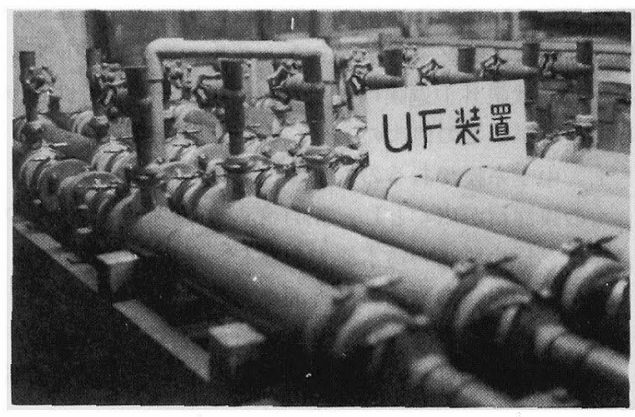

図 3 限外沪過装置工業化例 (モジュール本数 14 本)

ようになっている。この操作により, 通常目詰りを起こ し易い液や濃縮分極層が自動的に洗浄除去され，高い透水
能力を長期間維持出来るように設計されている。困 3 に は，契際に，上記システムを組み込み工業的に使用され ている装罡例を示す。

上記の如く，開発したポリアクリロニトリル系中空系 膜限外洰過装置は，他社輸入膜よりも上市化時期が比較 的浅いにも拘わらず, 数々の特性を有している為, 国産 膜である事の利点と相俟って, 各種の工業用途, 具体的 には, 電着塗料の回収, ラテックス等エマルション濃縮 回収, 無機コロイドの脱塩濃縮, 繊維処理油剤や水溶性 切削油の濃縮, ワクチン精製, 医薬品製造精製(除蛋白 及びパイロジェン除去)，無菌水の製造等各種の工業用 途に着実な実績を築きつつあり，更に今后もその適用市 場を拡げながら，省資源化，無公害化プロセスとして， 時代の要請に㐫じて行き度いと考えている。

(昭和 51 年 9 月 20 日受理)

\title{
6.4 PVA系多孔質シート
}

1.はじめに

従来からある布, 紙, 金網といった多孔性のシート素 材は今な打産業界で広く利用されているが, 近年の高分 子化学の発展は，多くの有用な多孔質シートを産業資材 として送り出して来ている。これらの素材は表 1 に示す ような分野で確固たる地位を築いている。

特に連泡系の素材において顕著な発展がみられ，電子，

\section{表 1 多孔質素材 (高分子系)}

\begin{tabular}{|c|c|}
\hline \multicolumn{2}{|c|}{ A. 連泡系 } \\
\hline (1) & 不絊布 \\
\hline (2) & ポロメリック (人工皮革) \\
\hline (3) & 電池隔膜 \\
\hline (4) & 高性能汇材, 除菌洰材 \\
\hline (5) & 透過性膜 \\
\hline \multicolumn{2}{|c|}{ B．独泡系 } \\
\hline (1) & 緩遦材 \\
\hline (2) & 防音材, 断熱材, 防振材 \\
\hline (3) & 浮揚材 \\
\hline
\end{tabular}

Polyvinyl Alcohol-Formaldehyde Porous Sheet MASAO HAYASHI and TETUO SEKIGAWA* Kanebo, Ltd. Industrial Materials Laboratory Researcher 鐘紡（株）産業資材研究所

\section{林政夫・関川澈夫*}

電気化学, 食品, 発酵, 医療, 薬品, 分析といった分野 では，多孔質シートは不可欠の素材といっても過言では ない。連泡系の場合, 主として気孔構造そのものが村質 等の特性に優先することが多く，それだけ多様な応用が 考えられることになる。いずれにせよ，多孔性という共 通特性が広く利用され，多孔性素材の開発と産業技術の 発展が互いに影響しあって，進行することが望ましいわ けである。

ポリビニルアルコール(以下 PVAと略記する)系多孔 質体は代表的な連泡系素材であるが，連泡という気孔特 性に加え PVAという材質特性が付与されていることか ら，非常に広範囲の利用がなされている。以下，PVA 系多孔質体の特性及び, 該シートの応用分野について述 ベる。

\section{PVA系多孔質体}

PVA系多孔質体は, PVA 水溶液に気孔生成助剤，丁 ルデヒド，酸触媒等を加え加熱反応せしめることにより 得られる。アルデヒドとしては, 通常ホルムアルデヒ ドが使用されるので，化学的にはポリビニルホルマール (PVF) 即ち,ビニロンと同様であり，ビニロンの有用 な特性の多くを受け継いでいる。

PVA系多孔質体は，更にアルデヒドで処理(高アセタ ール)したり, 樹脂処理, 或いは充填凮の添加等により各 
種の改質, 特性付与が可能である。特に他の素材と比較 して特徵づけられるのは, 気孔率およそ $90 \%$ 完全連泡 性に加えPVA系としての親水性と気孔径の多様性であ る。即ちPVA系多孔質体にあっては, 気孔径はおよそ

表 2 特性と応用, 用途

\begin{tabular}{|c|c|c|c|c|c|c|c|c|c|c|c|c|c|c|c|c|}
\hline \multirow{6}{*}{ 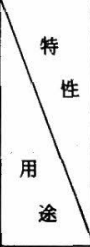 } & \multicolumn{8}{|c|}{ PVAの物生 } & \multicolumn{8}{|c|}{ 気孔生成法による特性 } \\
\hline & 親 & 瑓 & 典 & 強 & 弾 & 涌 & 棍 & 染 & 気 & $x$ & 拭 & 表 & 内 & 吸 & 㳂 & \\
\hline & & & 蔡 & & & & 和 & & 孔 & ; & & 面 & 部 & & & \\
\hline & 木 & 水 & & & 力 & $\dot{0}$ & to & 色 & 均 & $=$ & 浄 & 洰 & 洰 & 水 & 布 & \\
\hline & & & 品 & & & 哩 & 这着 & & - & 多| & & 過 & 過 & & & \\
\hline & 性 & 性 & 性 & 度 & 腰 & 五 & 牲 & 生 & 性 & 性 & 狌 & 性 & 性 & 性 & 性 & \\
\hline 洰過用 & & 0 & (a) & 0 & 0 & & & & (0) & (a) & & & (a) & & & (2) \\
\hline 洗拭用 & (a) & & & 0 & (c) & (c) & & 0 & 0 & () & (a) & & & (2) & & \\
\hline 美化栍用 & (a) & & & 0 & (a) & (a) & & 0 & 0 & 0 & & & & & (C) & \\
\hline 嗳木用 & (a) & & & 0 & (a) & (c) & & & 0 & & & & & & & \\
\hline 研磨用 & & & & (a) & & & 0 & & (a) & & & & & & & \\
\hline
\end{tabular}

(注) @印は特に強い特性
8〜1000 $\mu$ の範囲内で自由に調節され，かつ変性がなさ れたものを用途に応じて得ることができる。気孔の顕微 鏡写真を図 1 に，特性と応用用途を表 2 に示す。特に多 孔質シートとしての諸特性については表 3 , 表 4 に示す。

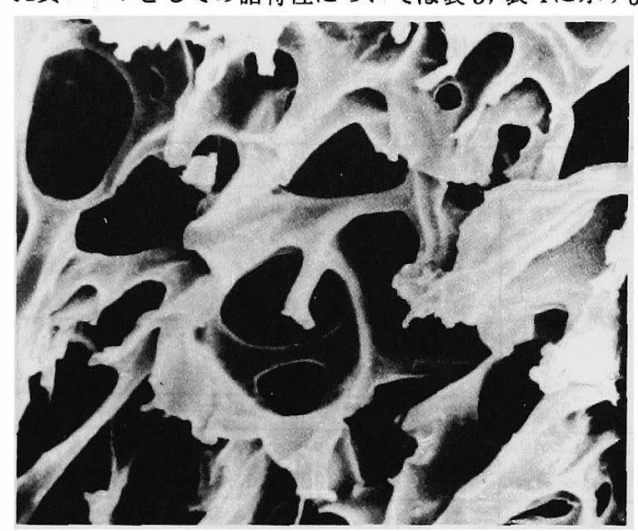

図 1 気孔写真

表 3 標準性状 (高ホルマール(*)品)

\begin{tabular}{|c|c|c|c|c|c|c|c|c|}
\hline 製品品番 ${ }^{(* *)}$ & A 3140 & A 3160 & A 3200 & A 3300 & A 3407 & A 3400 & A 3500 & D 3600 \\
\hline 漂準寸法 $\quad \mathrm{mm}$ & $400 \times 400$ & $400 \times 400$ & $700 \times 600$ & $1,000 \times 1,000$ & $1,000 \times 500$ & $870 \times 870$ & $1,000 \times 1,000$ & $870 \times 870$ \\
\hline 厚 さ & \multicolumn{8}{|c|}{$1 \sim 20$} \\
\hline 平均孔佳 & 8 & 30 & 60 & 130 & 300 & 350 & 700 & 1,000 \\
\hline 見措比重 $\mathrm{g} / \mathrm{cc}$ & 0.15 & 0.12 & 0.15 & 0.11 & 0.11 & 0.10 & 0.10 & 0.15 \\
\hline 氛孔率 加 & 86 & 91 & 88 & 91 & 91 & 92 & 92 & 88 \\
\hline 引張強さ $\mathrm{kg} / \mathrm{cm}^{2}$ & 26 & 18 & 24 & 15 & 10 & 8 & 8 & 23 \\
\hline 伸 び 另 & 37 & 30 & 39 & 21 & 26 & 26 & 13 & 11 \\
\hline $\begin{array}{l}\text { 王縮强さ } \mathrm{kg} / \mathrm{cm}^{2} \\
25 \text { 変 }\end{array}$ & 5 & 3 & 12 & 6 & 4 & 4 & 4 & 5 \\
\hline 酎 熱 & \multicolumn{8}{|c|}{ 最高使用温度 80 C } \\
\hline
\end{tabular}

（*）ホルムフルデヒドによる高フセタール処理品。普通処理のものは低ホルマール品と称す。

（**）鐘紡合成化学（株） カネボウスポンジシート

表 4 P VF 多孔質体の耐薬品性

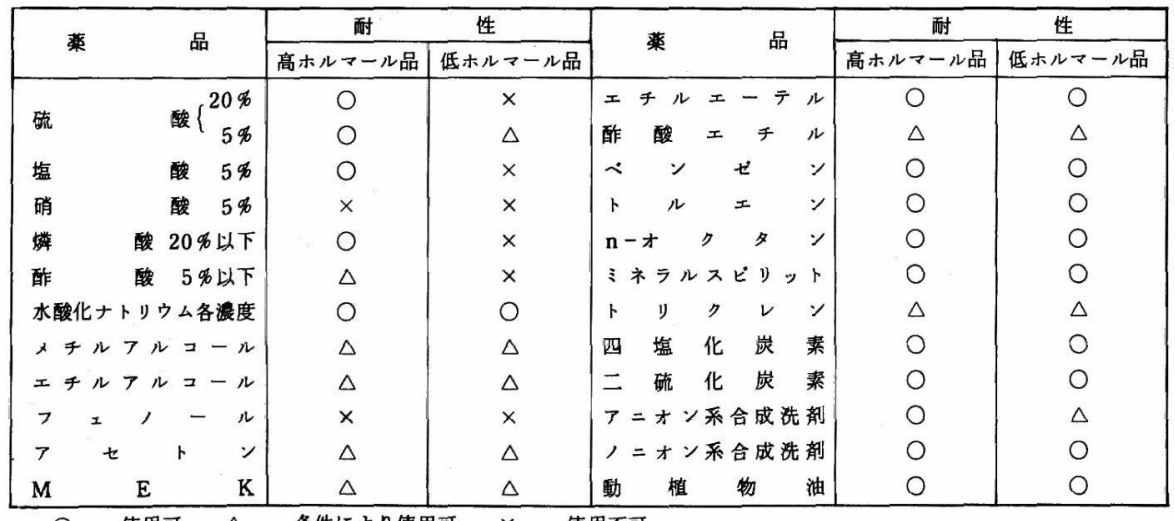

○……使用可, $\Delta \cdots \cdots \cdot$ 条件により使用可， $\times \cdots \cdots \cdots$ 使用不可 


\section{3. 応用分野，用途}

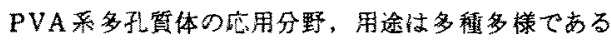
が、いずれにせよ大なり小なりその多孔性を活用したも のである。その使用状沇を裁 5 に示す。

\begin{tabular}{|c|c|c|}
\hline 琵 & A 䢞 & 鰨 \\
\hline \multirow{3}{*}{ 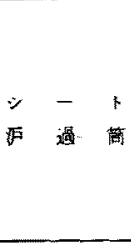 } & 昰体证通 & 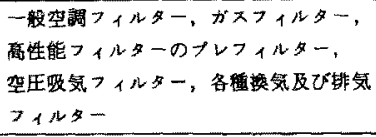 \\
\hline & 液化形遇 & 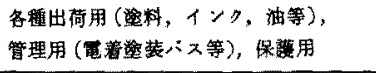 \\
\hline & 敬离用 & 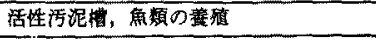 \\
\hline 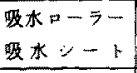 & 吸 & 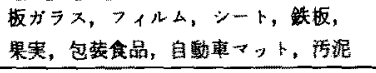 \\
\hline 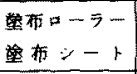 & 筮 标 & 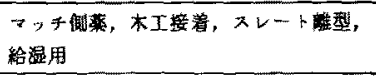 \\
\hline 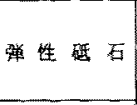 & 酷 & 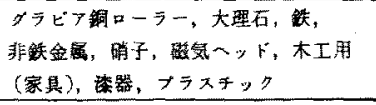 \\
\hline$\infty$ & $\begin{array}{l}\text { 洗拭用 } \\
\text { 美化胜用 } \\
z の \text { 把 }\end{array}$ & 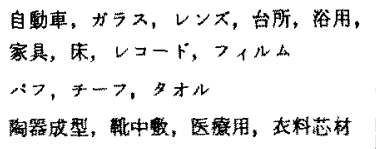 \\
\hline
\end{tabular}

4. あとがを

多孔買ンートそれ白体は本来の監発用途を持っている にせ上，更に改質，複合化等を進めることにより棈極的 に他用途を開発して行くへきであるら。この様な用途注，

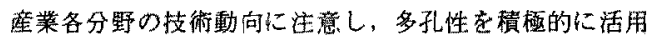
することにより開けてくるものと思われる。

\section{文藏}

1)牧，小叹田：ナラスチックフォームハンドブック（日扴工業新 閶新)

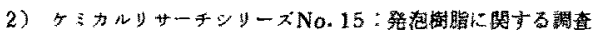
(CMC)

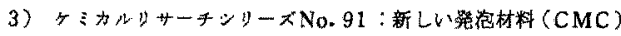

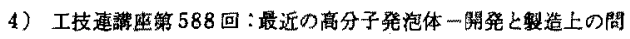

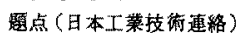

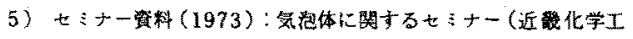
策会)

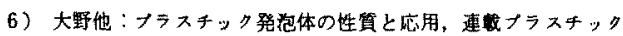
xイシ, $10(1970) \sim 3(1972)$

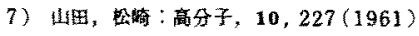

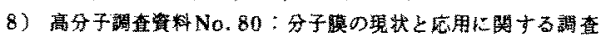

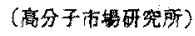

9)、青木：ラッーダイシェスト，24，(8〜10)，(1972）

10) ケミカルリサーチシリーズNo.159:凉分子膜 (CMC)

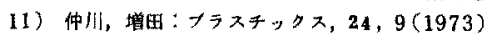

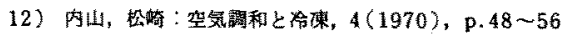
(昭积 51 年9月20日受理) 